\title{
Construction of ropeways in Slovakia in terms of pre-construction design using helicopters (case study)
}

\author{
Andrej Bisták ${ }^{1}$, and Zdenka Hulínová ${ }^{1, *}$ \\ ${ }^{1}$ Slovak University of Technology in Bratislava, Faculty of Civil Engineering, Department of \\ Building Technology, Radlinského 11, 81005 Bratislava, Slovakia
}

\begin{abstract}
Ropeways usually provide access to locations inaccessible to other means of transport. Due to this fact, the construction of ropeways is extraordinarily taxing in terms of both, technology and logistics. The site location is often in terrain difficult to access, which often precludes deployment of common construction mechanisms in ropeway construction. In such case, it is advisable to deploy a transport mechanism independent of the terrain - a helicopter. Functioning as "flying cranes", the helicopters have been used in construction industry in Slovakia for six decades now. Having amassed positive experience, even the "conventional" construction industry of the time, especially its ropeway transport segment, started to use the benefits of helicopters, with helicopter deployment subsequently gaining ground and becoming the mainstream technological procedure. Ropeway construction can hardly be feasible without them even nowadays. Throughout the history of helicopter deployment in construction industry, a constant search of improving the efficiency of their work has been under way, necessitated by the helicopter's sensitivitiy to weather conditions and work procedures alike. The paper presents an analysis of the factors affecting helicopter operation together with a proposed methodology of modeling their work in simulation models and the benefits of such approach.
\end{abstract}

\section{Introduction}

Because of its properties, many segments of industry use the helicopter as a practical and irreplaceable means of transport. The helicopter's capacity of vertical takeoff and landing, independent of long runways, makes this aircraft exceptionally suited for wide range of deployments, not requiring spacious or specifically suited surface for landing or takeoff. Unusual maneuvering capabilities allow helicopters to fly even in close proximity to the terrain. Its lower than other types of aircraft speed poses an advantage in heavy load transport [1].

\footnotetext{
* Corresponding author: zdenka.hulinova@,stuba.sk
} 
The helicopter is capable of flying in all directions and, unlike conventional aircraft, it can also stop mid-air - hover. It is precisely the combination of these characteristics that facilitates the use of helicopters also in the construction industry [2].

\section{Development of aerial work in the territory of present-day Slovakia}

Speaking of our experience, the era of helicopter deployment in construction industry began in 1957 in former Czechoslovakia, when several parts of technical equipment were transported onto the roof of a 42-m-tall building with a helicopter [2]. In 1961, the former Czechoslovak Airlines began to experiment with helicopter-aided construction work (also known as aerial work), purchasing the $2 \mathrm{Mi}-1$ and Mi-4 helicopters for that purpose. The period up to 1968 was the one for testing the possibilities of helicopter use in various kinds of construction work.

However, the helicopters Mi-1 and Mi-4 respectively, lacked sufficient load carrying capacity (max. $200-1300 \mathrm{~kg}$ ). Moreover, they featured only one piston engine. In the wake of the Mi-4 helicopter crash during dismantling of a freight cable car in 1966 in Sirk, these "experiments" were suspended and the search for a more suitable helicopter model, one that would meet all the requirements for aerial works [3], began.

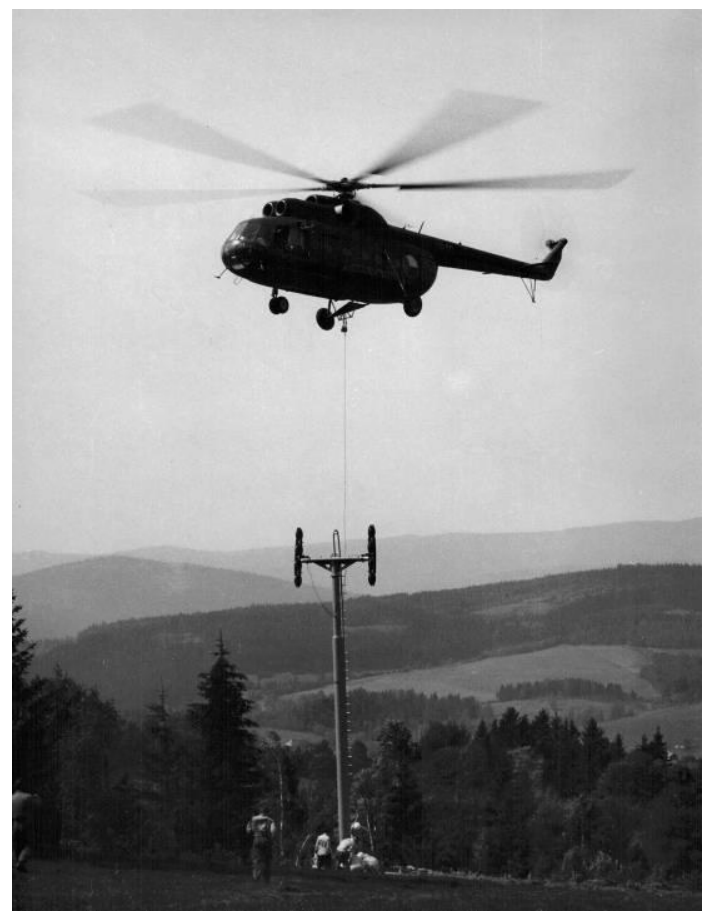

Fig. 1. Erection of pipe supports of the Špičák - Pancír chairlift ropeway.

In 1967, the new Mi-8 type aircraft - still widely used - was launched. In the very same year, two Mi- 8 helicopters were acquired by the Czechoslovak army. The helicopters were assigned to the Military Aviation and Research Center 031 Prague-Kbely, which proceeded with a test flight in March 1968, with the helicopter carrying a suspended load of a steel support pillar for the ropeway, to be erected at a precisely-defined target destination. The 
results of these tests showed that the helicopter of the Mi-8 type met all aerial work requirements. In addition, they confirmed the following assumptions:

- the values of normal vertical load-bearing operating speed obtained from Mi-4 helicopter corresponded with the expected value of $5-10 \mathrm{~cm} / \mathrm{s}$, which was in line with the hoist speed of the majority of conventional cranes at the time,

- a lengthy load (suspended pipe supports ranging from 5 to $20 \mathrm{~m}$ ) and varying flight speed $(0-90 \mathrm{~km} / \mathrm{h})$ did not cause flight disruption,

- significant vertical swinging of the load, which impeded precision mounting conditions, was observed during the test of achievable horizontal accuracy at the final mounting stage of the support onto the base foot [3].

Following the completion of the test flights, a technological procedure was developed, and preparations for the first mission were made - i.e. the transport and erection of 35 pipe supports of the Špičák - Pancír chairlift in Železná Ruda in the Czech Republic (Fig. 1) Erection of supports took place between May 28 and June 1, 1968. Despite unfavorable weather (rain, low-level clouds and strong wind), the erection processes were completed in $5 \mathrm{~h} 38 \mathrm{~min}$ net flight time. The entire mission took only 10 business days, from the preparation stage all the way to completion. The erection time of conventional technology was estimated at 73 business days and the estimated price exceeded CZK 297,253.70 [3].

Positive experience with this construction encouraged further development of the "helicopter program". The main initiator of helicopter utilization in the entire construction industry was Transporta Chrudim, the producer of these cableways, with a monopoly in the respective field in Czechoslovakia at that time. It was the assembly plant's Tramontáž utmost interest to make the construction work under demanding conditions, still undermechanized at that time, more efficient [4].

Before the end of 1970, helicopter properties suitable for construction work were being verified outside the "cableway" industry, too. These included, for example, erection of power towers, pipe bridge installations, reconstructions of obsolete production halls with complicated access, erection and dismantling of steel funnels and equipment on roofs of production halls, installation and dismantling of antenna systems, tower cranes, etc.[3]

Other "prototype" missions in the cable transport segment followed as well. After successful erection of chairlift ropeway supports, technical development at the Tramontáž plant focused on verifying the erection possibilities of cable car ropeway supports [3]. Unlike the chairlift ropeway supports, these supports had a truss structure and were typically of substantially larger dimensions, resulting in greater weight.

Testing of this type of work was carried out at the construction of Tatranská Lomnica Štart - Skalnaté pleso cable car ropeway in the High Tatra Mountains. This mission necessitated erection of 4 cableway supports (Figure 2a). The support structure was designed as a truss structure with flange connections in individual sections - blocks division plane (Fig. 2b).

The individual sections were connected to each sidewall with only one flange joint and lacked both, the lower and the upper transverse connection, that would result in creation of a section forming a separate rigid block. The exception was only the lower anchor section fitted with transverse wind bracing. In order to transport sections assembled in this way by a helicopter, the sections had to be supplemented with auxiliary rods during transport and erection.

With the use of a crane, all blocks of pre-assembled supports were pre-assembled on the pre-assembly area, located next to the football pitch in Tatranská Lomnica. The supports were 20 to 41 meters tall and consisted of $4-8$ blocks weighing $750-2300 \mathrm{~kg}$. The pitch itself was used as a helicopter takeoff, landing and refueling area. Individual blocks were transported from the pre-assembly area to erection destination (support base feet) over the air distance of $4600-5000 \mathrm{~m}$. 


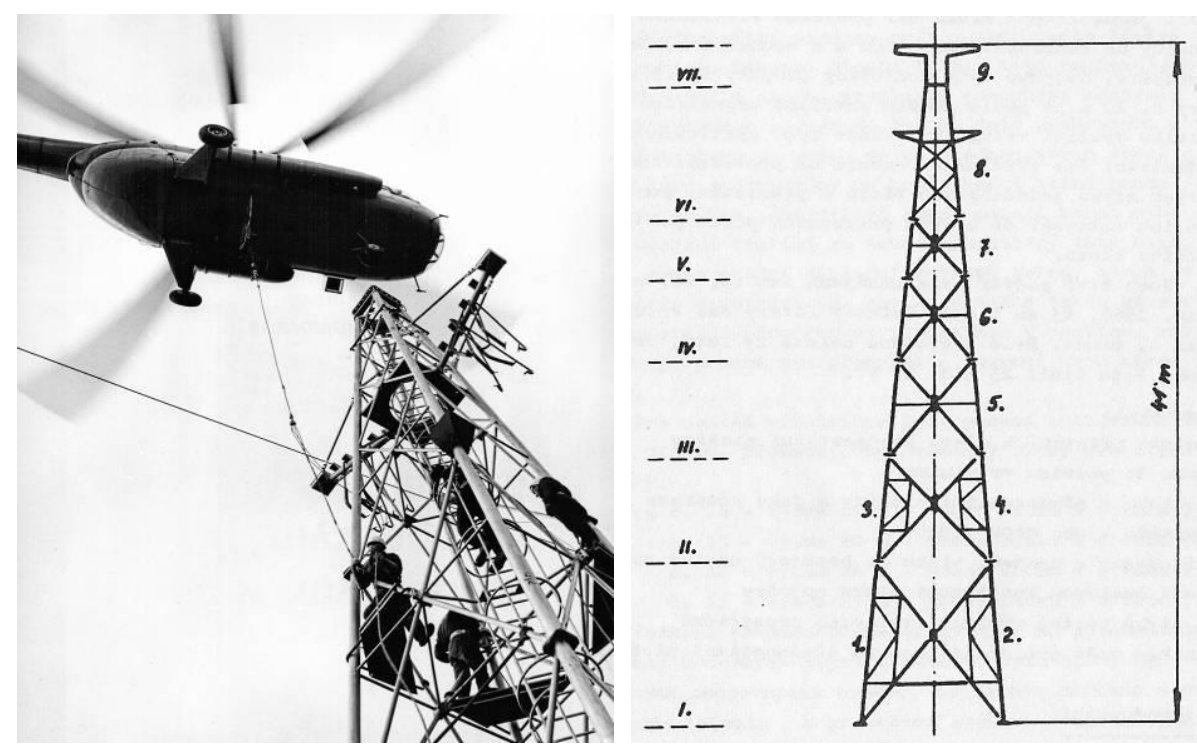

Fig. 2. a. Erection of truss supports of the cable car ropeway Tatranská Lomnica - Skalnaté Pleso. b. Typical truss support assembly with marked blocks. Source: [3]

The erection of supports began on October 14 and finalized on October 19, 1968. It took 5 business days. Total helicopter flight time was 9 hours 16 min. over 25 flights, averaging 25 min. $12 \mathrm{~s}$. When the mission was successfully accomplished, it was established that the price for helicopter-aided erection was $660,798 \mathrm{CZK}$ lower than would have been the price of erection using conventional technology and the erection time was reduced by 121 business days [3].

Subsequently to these verification tests, all the chairlift ropeway supports listed below were erected by Tramontáž assembly plant in helicopter-aided erections. The following ropeways were erected, among others, in the first "series" erections before 1974:

- Štrbské Pleso - Solisko (High Tatras),

- Železná studnička - Kamzík (Bratislava),

- Turecká - Krížna (Vel'ká Fatra),

- Banská Bystrica - Srnková (Banská Bystrica),

- Podstráne - Martinské hole (Martin) - a cable car located in a very difficult terrain, with a $110 \mathrm{kV}$ power line, powering the transmitter, running in the forest clearing alongside the constructed ropeway route. This complicated construction was successfully completed in June 1973 [3].

\section{Present day helicopter-aided aerial work in ropeway transport}

The nature and application of aerial work in the construction of ropeways has practically remained unchanged. Currently, helicopters are used in construction of almost every new ropeway in the Slovak Republic. In recent years, these included ropeway construction in Oravská Lesná - Kohútik, Krupová - Kosodrevina (Chopok South), Ždiar - Vtáčie turne, Roháče - Spálená, Lúčky - Vyhliadka (Chopok North) and Štart - Skalnaté pleso (Tatranská Lomnica) among others. One of the most closely watched missions was the construction of a new ropeway linking the north and the south side of the mount Chopok in 2011 - 2012 (Priehyba - Chopok from the North and Kosodrevina - Chopok from the South). 
Present-day ropeways require a greater number of flights compared to the abovedescribed older erections due to greater load of structural elements and the associated increase in steel structure dimensions. Due to greater weight of supports, which exceeds the carrying capacity of the helicopter, the supports are designed as a set number of segments., These segments are joined on site by threaded joint flanges, while precision mounting of the parts is ensured by assembly fittings.

Therefore, completion of a single support requires several flights. For this purpose, the ropeway machinery manufacturer provides the aerial work contractor with tables indicating the exact number of parts, their dimensions (lengths) and weights, on the basis of which the contractor prepares the technological procedure for erection, in particular allocating the segments to individual flights.

In Slovakia, aerial work is subject to an authorization issued by the Transport Authority. In its authorization, the Authority specifies the scope of and the conditions for aerial work execution. According to the Register of the Civil Aviation Division, there are two companies operating on the aerial construction work market at present: UTair Europe, s.r.o. (the Piešt'any Airport) and TECH-MONT Helicopter Company, s.r.o. (Spišská Nová Ves Airport) [5].

\section{Structural and technological preparation of aerial work}

Currently, deterministic models are prevalent in structural and technological preparation of construction, in which reality is approximated through application of suitable coefficients. The models thus created are relatively simple, yet sufficient to plan technological processes under certain circumstances. However, in case of construction under more complicated conditions, the deterministic approach may be distortive due to incidental changes.

An optimal model of the construction process should reflect especially its incidental nature. Incidental factors that may affect the course of construction processes are, among other, the geological, hydrogeological and morphological conditions, the location of infrastructure, weather conditions, traffic situation, uninterrupted continuity of the supply network, quality of materials, breakdown rate of machines and equipment, design changes, financial flow, changes in deadlines, etc. [6]

Deterministic models make the actual course of aerial work more difficult to predict, in particular due to the specific nature of aerial work influenced by the already mentioned incidental factors affecting helicopter operation. Thus, inaccuracies in time and cost planning negatively affect the entire construction process, resulting not only in an adverse technical impact but also impeding the organization of the construction process and the coordination of sub-supplies [7].

If we allow for the effects of incidental factors, we can achieve desired outputs with probability to only a certain degree. The most accurate model of reality is achieved by imitating the real object using a simulation model. Unlike deterministic approach, this model is based on the creation of mathematical-logical models [6].

\subsection{Current situation in the field of simulation modeling in the construction preparation phase}

Simulation modeling is based on building a computer model of the construction process as it would actually be carried out and experimenting with the model thus assembled [8]. Simulation models can be created using multiple software, e.g. ExtendSim or MATLAB.

Simulation is not a tool that would directly deliver the right solution. Simulation modeling is rather a supportive tool, assisting the contractor's decision making in case more solutions of how to complete the construction process present themselves. It helps the 
contractor choose an optimal construction technology based on the output values of individual options [6].

The research on the use of simulation modeling in the construction preparation phase has been the focus of several authors, e.g. Mahmoodzadeh and Zare [9], who researched the probabilistic prediction of the impact of expected geological conditions, the duration of construction and the total cost of road tunnels. Alsudairi [10] proceeded likewise analyzing the possibilities of simulation approach in reducing construction costs, shortening construction time and building maintenance.

Several authors have already dealt with simulating weather conditions and assessing their impact on the construction process. These authors have successfully used the simulation approach (e.g. Lee et al [11], Jung et al., [12]) to assess the significance of this impact. However, they simulated only "conventional" construction processes using conventional cranes and other conventional construction machinery [13-15].

Research on simulation modeling in construction preparation phase is therefore only at the beginning, with several authors emphasizing the need to publish further studies using simulation approaches.

\subsection{Aerial work simulation model concept}

The simulation model of aerial work should account for incidental factors, including the above-mentioned weather conditions, which affect the helicopter's operation most, thereby influencing its most important feature - the maximum achievable load carrying capacity.

This part of the algorithm can be created in a number of ways, each providing predictive data for various lengths of time. On the Slovak market, it is the Slovak Hydrometeorological Institute (SHMÚ) that offers the numerical predictive model of the European Center for Medium-Range Weather Forecasts (ECMWF), as well as the numerical model ALADIN, continuously developed directly at SHMÚ [13].
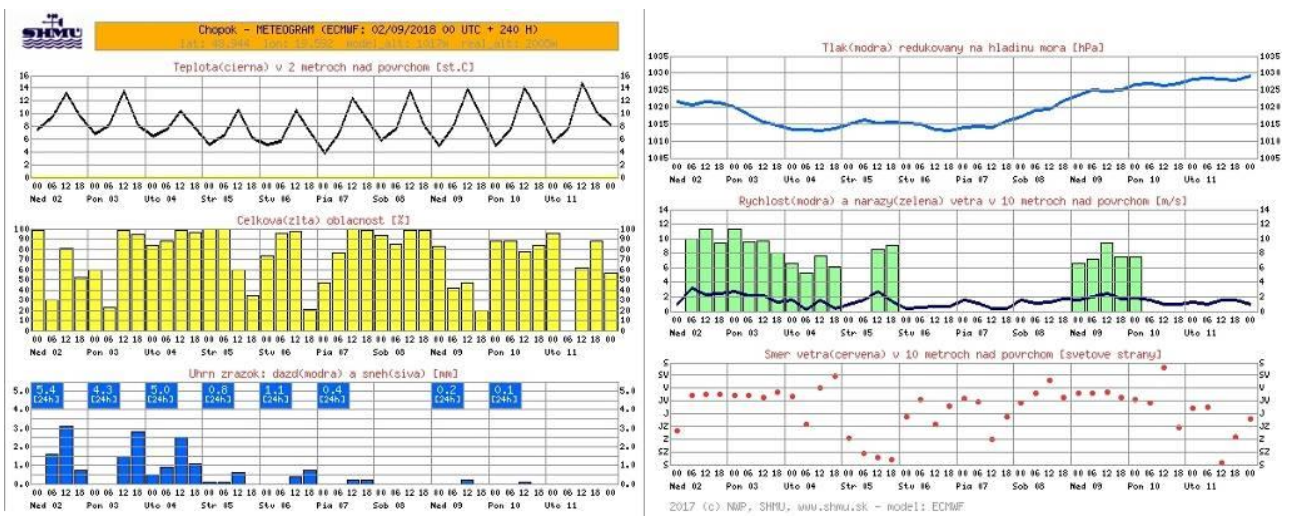

Fig. 3. Meteograph of the geographic point of Chopok according to ECMWF model. Source: [16]

The ECMWF numerical model provides medium-term probability predictions for the next 10 days. The model's output is the predicted time course of individual meteorological elements. These are presented graphically in the form of a meteograph (Fig. 3), which summarizes the individual outputs of the predictive model relative to the specific geographic point - selected location [13].

The algorithm of the simulation model also considers the helicopter technical and economic parameters, e.g. price per flight hour. Likewise, it observes the technological, organizational and legislative regulations and principles applicable to aerial work. When 
compiling the simulation model, the knowledge of the relevant local legislation is of crucial importance, as it gives rise to many requirements or limitations. By their nature, the aerial work belongs under the broader CAT (Commercial Air Transport) category.

The main Slovak legislation in this area is the Act no. 143/1998 Statutes on Civil Aviation (the Aviation Act), as amended. An important aviation regulation is also the "JAR-OPS 3 Commercial Air Transport (Helicopters)" issued by the former Joint Aviation Authorities (JAA). Today, this area is under the auspices of the European Aviation Safety Agency (EASA).

The simulation model outputs are then implemented in the construction and technological processes. This means that based on the results of the simulation model, the basic technological documents (construction schedule, financial plan, etc.) will more accurately copy the real construction process. Simulation of aerial work consists of the following steps:

1. photographing the course of the helicopter-aided construction processes (especially concrete casting and erection processes) in order to gain complete knowledge of the sequence and duration of the processes carried out on the site, including the interconnections and interdependencies between the processes,

2. compiling the simulation scheme of the observed construction processes using the knowledge acquired by photographing those processes,

3. creating the simulation model of the construction process based on the proposed simulation scheme and obtaining a picture of the real course of the process through the outputs from the individual simulation runs,

4. verifying the compiled simulation model by comparing its outputs with the outputs of the actual processes already carried out,

5. comparing simulation modeling outputs with the outputs based on the deterministic approach with the aim of evaluating the significance and effectiveness of simulation methods in construction preparation phase.

The aerial work model under consideration will allow to verify the possibility of using the simulation approach in this under-researched area of construction production. It will thus contribute to broader application of progressive simulation modeling tools in construction practice and will also create a framework for development of institutional simulation training. It is these tasks that several contemporary authors designate as the most pressing. The presented topic belongs to the field of interdisciplinary research. Therefore, the obtained results could also be useful outside the construction industry, especially in logistics as such.

\section{Conclusion}

Helicopter deployment has provided the construction industry with a means of carrying out construction even under difficult natural conditions, i.e. in ropeway construction. Yet demands for the construction preparation phase of such structures have increased. Planning and organization of construction preparation work calls for the use of state-of-the art approaches, such as simulation modeling, which allows us to get closer to reality, to identify all incidental influences and to eliminate their consequences.

The authors of the paper thank Leitech, s.r.o., Bratislava and UTair Europe, s.r.o., Bratislava for assistance and cooperation, and Mr. Miroslav Holub, a former employee of Transporta Chrudim, for providing historical photographs. The paper is a part of the research grant project "Progressive Methods of Preparation of Aerial Work in Construction Industry Using Computer Simulation" supported by the Program for Support of Young Researchers of the Slovak University of Technology in Bratislava. 


\section{References}

1. V. Messingerová, Technológia vzdušnej dopravy dreva v lesníctve [Technology of air transport of wood in forestry] (Technical University in Zvolen, Zvolen, 2005, ISBN 80-228-1523-3)

2. F. Jindra, Stavebně montážní práce s využitím vrtulníků v ČSSR [Construction work using helicopters in Czechoslovakia] (NADAS, Praha, 1965)

3. J. Boudník, E. Dosoudil, Využitie vrtulníkov v národnom hospodárstve [Use of helicopters in the national economy] (Dom techniky SVTS, Bratislava, 1974)

4. V. Hrubeš, Využití vrtulníků v osmdesátých letech v ČSSR [The use of helicopters in the Czechoslovakia in the 1980s], In: Využitie vrtul'nikov v národnom hospodárstve zborník prednášok, Tatranská Lomnica, 18. - 19.10.1988 (Dom techniky ČSVTS, Žilina, 1988, pp. 16-19)

5. Letecké práce [Aerial Works] [online]. Bratislava: Transport Authority 2018 [viewed 2018-08-12]. Available from Internet: http://letectvo.nsat.sk/letovaprevadzka/osvedcenie-letovej-sposobilosti/formulare/

6. Z. Hulínová, Analýza stavebných procesov z hladiska ich modelovania [Analysis of construction processes in terms of their modeling] (Slovak University of Technology, Bratislava, 2011, ISBN 978-80-227-3474-5)

7. B. Chamulová, Scheduling incorporating project priorities and changes (Tribun EU, Brno, 2016, ISBN 978-80-263-1148-5)

8. S. Abourizk, D. Halpin, Y. Mohamed, U. Hermann, J. CONSTR. ENG. M. 137, 843$852(2011)$

9. A. Mahmoodzadeh, S. Zare, JRMGE, 8, 734-745 (2016)

10. A.A. Alsudairi, Procedia Engineering, 118, 1086-1095 (2015)

11. H.-S. Lee, J.-W. Shin, M. Park, H.-G. Ryu, J. CONSTR. ENG. M. 135, 1289-1298 (2009)

12. M. Jung, M. Park, H.-S. Lee, H. Kim, J. CONSTR. ENG. M. 142 (2016)

13. V. Molnar, G. Fedorko, J. Kresak, P. Peterka, J. Fabianova, Eng. Fail. Anal. 74, 119132 (2017)

14. V. Molnar, J. Boroska, J. Decmanova, Acta Montanistica Slovaca, 15 Special Issue 2330 (2010)

15. G. Fedorko, H. Neradilova, J. Jackanin, Adv. In Sc. And Technol.-Res. Journal 12(2), 170-179 (2018)

16. Model ECMWF - popis [Model ECMWF - description] [online]. Bratislava: Slovak Hydrometeorological Institute 2018 [viewed 2018-08-12]. Available from Internet: http://www.shmu.sk/sk/?page=1164 